В. А. ПОГОЖЕЛЬСКИ

\title{
СХЕМА ТЕОРЕМ О ДЕДУКЦИИ \\ ДЛЯ ИСЧИСЛЕНИЯ ВЫСКАЗЫВАНИЙ
}

(

В работе дана общая схема формул называемых теоремами о дедукции для исчисления высказываний а также определение формул типа теоремы о дедукции (для исчисления высказываний).

W. A. POGORZELSKI

\section{A SCHEMA OF DEDUCTION THEOREMS FOR THE PROPOSITIONAL CALCULUS}

(Summary)

Gives a general schema of the formulas termed deduction theorems for the propositional calculus, and a definition of the formulas of the type of a deduction theorem (for the propositional calculus). 